\title{
不法投棄現場のVOC污染地下水の浄化プロセス の評価とその対策に関する研究
}

\author{
西田 憲一 ${ }^{1} \cdot$ 古市 徹 $^{2} \cdot$ 石井 一英 ${ }^{3}$ \\ ${ }^{1}$ 非会員 三重県環境森林部廃棄物対策室 主查( T518-8570 三重県津市広明町 13 番地) \\ (北海道大学大学院工学院＼cjkstart博士後期課程 $(\bar{T} 060-8628$ 札幌市北区北 13 条西 8 丁目 )) \\ E-mail: nishin07@pref.mie.jp \\ ${ }^{2}$ 会員 北海道大学大学院工学研究院 教授 $(\bar{T} 060-8628$ 札幌市北区北 13 条西 8 丁目) \\ E-mail: t-furu@eng.hokudai.ac.jp \\ 3 会員 北海道大学大学院工学研究院 准教授 ( $\bar{T} 060-8628$ 札幌市北区北 13 条西 8 丁目) \\ E-mail: k-ishii @eng.Hokudai.ac.jp
}

\begin{abstract}
産業廃棄物を残置したまま実施する不法投棄現場の地下水の原位置浄化は，廃棄物の全量撤去に比べて 経済的負担が少ない重要な技術であり，その社会的必要性は高い。本研究では，三重県桑名市の不法投棄 現場を対象として, 複数の揮発性有機化合物(VOC)により污染された地下水を, 地下水揚水循環浄化工法 により 5 年間で目標レベルまで浄化することを試みた。その結果，浄化目標達成には，本研究で提案する 複数のVOCを統合的に評価する指標である加重平均濃度とその等濃度分布図の作成による地下水浄化過程 の把握, 污染残留箇所の特定, 計画見直し, 追加的な浄化促進対策の実施を一連のプロセスとして実施す ることが重要であることを明らかにした.
\end{abstract}

Key Words: remediation process, groundwater contamination, illegal dumping site, in situ flushing, on-site remediation

\section{1. 研究背景}

産業廃棄物の不法投棄の件数及びその量は, 近年, 減 少傾向にあり，2009 年度に新たに判明した件数は 279 件, その量は 5.7 万トンであり, 平成 7 年度からの統計にお いて最少となっている ${ }^{1)}$. 一方で，これまでの不法投㶳 及び不適正処理事案の残存量は, 廃棄物の撤去が遅々之 して進まないことから増加の一途であり, 平成 21 年度 末には約 1,730 万トンと膨大な量となっている ${ }^{1)}$.

残存する廃棄物の是正は急務であるものの, 投棄され 長期間放置されたたままの廃棄物は，原因者やその関与 者, 排出事業者が不明となる場合もあり, さらに 10 万 トンを越える大規模事案では, 受け血となる処分先の確 保が困難で，かつ多大な費用が必要となるために，撤去 等がなされず廃棄物が放置され，ストックとして残存し てしまう。

不法投棄等不適正処分された廃棄物を放置することは,
景観を害し，ブラウンフィールド問題や新たな不法投充 の誘発を招くおそれがある。 そして, 産業廃棄物に対寸 る負のイメージが新たな処理施設の整備を妨げ，処理・ 処分先の確保が困難となり，処理費用の高騰，不法投棄 等不適正処分の発生という, 廃棄物処理に係る社会シス テムが負のスパイラルに陷ることが䀣念されている.

また，放置された廃棄物から有害物質等が浸出し，土 壌污染, 地下水污染等を引き起こす事案も発生している. こうした事案のうち, 原因者等による是正措置が講じら れず, 残存する廃棄物により崩落や有害物質の拡散等生 活環境保全上の支障等が生じている場合は, 行政代執行 により公費（税金）による支障除去等事業が実施される. 特に, 廃棄物処理法の規制が強化される前の 1998 年 6 月以前に発生した事案は, 発生から長期間が経過し, か つ, 大規模事案が多いことから, 原因者等による是正が 進まず社会問題化し，国は，2003 年 6 月に産廃特措法 を制定し，行政（地方自治体）による支障除去等事業を 
進めている22.

産廃特措法に基づく大規模事案の行政代執行において は, 香川県豊島事案や青森・岩手県境不法投㶳事案を除 き，事業費の低減を図るため廃棄物の全部又は一部を現 地に残置寸る原位置環境修復工法が採用されているが, 不法投棄された廃棄物は，その種類や形状，埋立の粗密 の程度など，同一サイト内でも埋立された時期ごとに異 なっており，こうしたことにより廃棄物層は不均一であ ることから，その浄化は容易でない ${ }^{3)}$.

行政代執行の環境修復工法の決定においては，早期の 有害物質等の除去による安全確保が求められるが，廃棄 物を現場に残置した場合には不安感が取り除かれないこ と等から，住民が全量撤去を求め，多大な費用の支出を 避ける行政と対立する事態も発生している。 しかし，原 位置環境修復技術は，限られた財源で生活環境保全上の 支障等を除去する有効な手法の 1 つといえる ${ }^{4}$.

原位置環境修復技術は，土畩污染対策の現場で土壌及 び地下水の浄化に対して多数実施事例があり, その研究 に関寸る報告例は多い ${ }^{5)}$ 。一方，廃棄物不法投棄現場 において，廃棄物を残置した原位置環境修復技術につい ては，多くの自治体で実施中であるが，浄化対象場所に 污染源となる廃棄物を残置し揚水循環浄化を実施した事 例はなく，今後も新たに着手する場合も生じることから， 研究の必要性は高い. 特に, 廃棄物層内では, 浸出水, 埋立ガス，熱などが複雑な物質移動現象を生じているこ とから, 原位置環境修復の実行段階における詳細な調查 や解析，結果の評価などを踏まえて，その浄化過程を明 らかにする必要がある。

そこで，本研究では，三重県桑名市の不法投棄事案を 対象として, 有害物質の偏在や埋立廃棄物の種類, 埋立 方法が無秩序であるという廃棄物層の不均一性を前提と して，地下水揚水循環净化工法により廃棄物を残置した まま 5 年間で目標とするレベルまでの地下水浄化を試み た. 污染地下水の揚水浄化は, 時間経過とともに污染物 質の回収量が減少し，対策期間の長期化やコストの増嵩 といった課題が知られているが，本研究では，目標とし た 5 年間で地下水浄化を達成するため, 地下水浄化プロ セスを，計画策定(Plan)，対策実施(Do)，実施結果の解 析・評価（検証:See）を1サイクルとする PDS による進 行管理を 3 サイクル実施し, 目標達成に必要な評価手法 を提案し, 追加措置等の地下水浄化プロセスについての 新たな知見を述べる.

なお，地下水浄化の一連のプロセスについて，PDS の 各サイクルを，次の3 段階の対策に区分した.
(1)当初計画に基づく対策（初期対策）

(2)初期対策の検証を踏まえた対策（第 1 浄化促進対策）

(3)第 1 浄化促進対策の検証を踏まえた対策（第 2 浄化促 進対策)

本論文では，廃棄物層の不均一性により間隙の比較的 大きな特定の流路（水みち）の形成が廃棄物層内の均等 な地下水浄化を妨げることから, 地下水調查結果を踏ま え, 污染残留箇所の浄化促進手法について述べることと し，地下水浄化の対象を廃棄物が存在している不法投棄 地内の上部带水層としている。

なお，不法投棄地内の下部帯水層及び当該場所周辺に 拡散した污染地下水の浄化については, 対策工として鉛 直遮水壁を設置し一部揚水浄化による対策を講じ浄化を 完了しているが，污染拡散メカニズム等の解析途中であ り，その浄化過程については本論文の対象としていない.

\section{2. 不法投棄による污染の概要}

\section{（1）三重県桑名市事案の概要}

桑名市は, 三重県北部に位置し東海道五十三次の 43 番目の宿場町として古くから栄えた町である. 本研究の 対象とする桑名市事案は, 東名阪自動車道の桑名 IC か ら北西約 $2.5 \mathrm{~km}, 2$ 級河川嘉例川が形成した河岸段丘の 右岸段丘面に位置する．その嘉例川から南に約 $50 \mathrm{~m}$ の場 所の山林を(株七和工業が不法投棄目的で掘削し，自社の ミ二処分場（当時, $3,000 \mathrm{~m}^{2}$ 未満は廃棄物処理法規制対 象外）之称し当該現場を使用していた。

(侏七和工業は，不法投衰場所の近隣で管理型処分場を 設置し産業廃棄物処理業及び解体業を営んでいたが, 1995 年頃, 管理型処分場の残余容量が減少したことか ら，容量確保のために既に埋立処分された燃えがら，鉱 さい, 廃プラスチック類等の廃棄物を掘削し, 掘り起こ した廃棄物とともに廃油を混入させ不法投棄した．その 約 2 年後の 1997 年 12 月に不法投棄場所の隣地で農業集 落排水処理施設の建設工事が行われた際, 切土面から油 分が浸出し不法投棄が発覚した.

不法投棄現場の掘削調查及びボーリング調査の結果, 広さ約 $3,000 \mathrm{~m}^{2}$ の範囲で廃棄物が確認され, 最大で深さ 約 $15 \mathrm{~m}$, 総量約 $27,000 \mathrm{~m}^{3}$ が埋設されていると推定された.

\section{（2）污染状況調査結果}

\section{a）廃棄物の性状と地下水污染の状況}

調査のため不法投棄場所の廃棄物を掘削し溶出試験を 実施したところ，管理型処分場で埋立処分できる基準 
(埋立判定基準) に対し，6 種のVOC が基準を超過して いた。 その濃度は, 最大でジクロロメタン $8.2 \mathrm{mg} / \mathrm{L}(41$ 倍)，1,2-ジクロロエタン $4.5 \mathrm{mg} / \mathrm{L}(11$ 倍), トリクロロ エチレン $2.5 \mathrm{mg} / \mathrm{L}$ (8.3 倍), テトラクロロエチレン 2.2 $\mathrm{mg} / \mathrm{L}$ (22 倍), ベンゼン $1.0 \mathrm{mg} / \mathrm{L}$ (10 倍)，1, 3-ジクロロプ ロペン $0.31 \mathrm{mg} / \mathrm{L}\left(16\right.$ 倍)であった ${ }^{6,7)}$.

表-1 不法投棄地内の地下水污染状況 (単位 : $\mathrm{mg} / \mathrm{L}$ )

\begin{tabular}{|c|c|c|c|}
\hline 物質名 & 調査結果 & 環境基準 & 基準值超過倍率 \\
\hline ジクロ吹 & 54 & 0.02 & 2,700 倍 \\
\hline 1,2 -ジクロ吅外 & 6.7 & 0.004 & 1,600 倍 \\
\hline 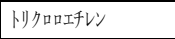 & 1.3 & 0.03 & 43 倍 \\
\hline テトラクロ听チン & 1.7 & 0.01 & 170 倍 \\
\hline ベンゼン & 1.2 & 0.01 & 120 倍 \\
\hline 1,3-ジクロロプロペン & 0.030 & 0.002 & 15 倍 \\
\hline 功、汸么 & 0.38 & 0.01 & 38 倍 \\
\hline 鉛 & 30 & 0.01 & 3,000 倍 \\
\hline 七素 & 0.66 & 0.01 & 66 倍 \\
\hline 総水銀 & 0.17 & 0.0005 & 340 倍 \\
\hline BOD & 15,000 & - & - \\
\hline COD & 6,400 & - & - \\
\hline
\end{tabular}

また，不法投棄現場の地下水は，廃棄物の溶出試験で 埋立判定基準を超過して検出された 6 種の VOC が地下水 においても環境基準を超過して検出され，特に，ジクロ ロメタンが最大で環境基準の 2,700 倍の濃度で検出され た（表-1）。また、BOD，COD の有機污濁指標も高い值を 示し, 廃棄物の埋立判定基準を超過していないカドミウ ム, 鉛, 水銀等の重金属も地下水の環境基淮を超過して いた，しかし，重金属は，地下水を濾過した検体で分析 したところ，環境基準值以下であったことから，廃棄物 が懸濁物質として混入していたと考えられた.

なお，不法投棄現場の周辺地下水においても，VOC が 環境基準を超過し, 最大でジクロロメタンが環境基準の 100 倍の濃度で検出されたほか, 高密度電気探査結果で は不法投棄場所から北東約 $40 \mathrm{~m}$ の地点まで低比抵抗区域

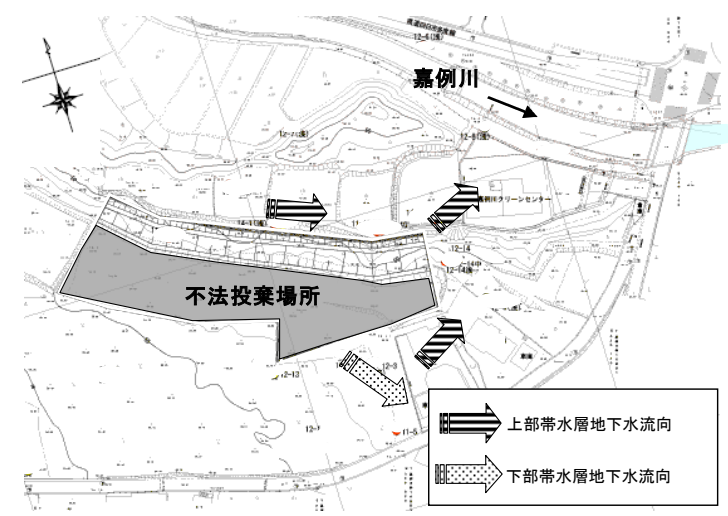

が認められ，周辺地下水への污染の拡散が確認された ${ }^{8)}$.

\section{b) 地質調查及び地下水流向}

不法投充地内及びその周辺のボーリング調查により， 当該場所は主に砂質土層及び碟質土層で構成され，標高 40m（GL-14m） 付近に連続性の高い 1 2m 厚の粘土層, また，標高 $32 \mathrm{~m}(\mathrm{GL}-22 \mathrm{~m})$ 付近に $10 \mathrm{~m}$ 以上の厚みを有す る凝灰質シルト層が確認された。 これら粘土層及び㠜死 質シルト層は, 難透水層となり, 当該場所の帯水層は上 部帯水層と下部帯水層に区分される.

帯水層ごとに観測用井戸を設置し, 水位標高から地下 水流向を推定したところ, 上部帯水層は, 嘉例川に流れ 込む北東方向, 下部帯水層は嘉例川の流下方向に平行す る南東方向であることが推定された（図-1）.

なお，推定された上部帯水層及び下部帯水層の地下水 流向は, 高密度電気探査により廃棄物から拡散した電解 質の影響と考えられる低比抵抗区域の分布範囲と一致し ていた.

\section{3. 環境修復の目標とその措置}

\section{(1) 工法選定}

2001 年に三重県が「不法投䢂事案に係る污染修復工 法等検討委員会」を設置して対策工法を検討した結 果, 図-2 に示寸鉛直遮水壁による污染拡散防止と 地下水の揚水循環浄化工法 ${ }^{9}$ が適当であると決定され た.

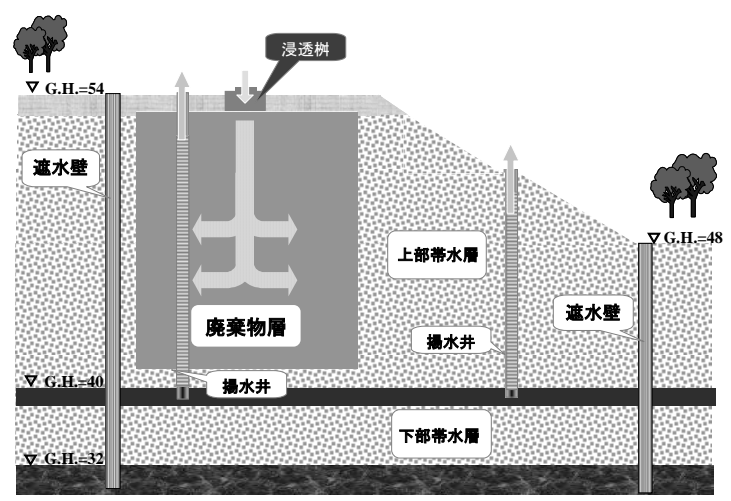

図-2 揚水循環净化の概念図

\section{(2) 修復目標}

不法投棄に起因した污染地下水がすでに周辺に拡散し ており，不法投棄場所北側を流下寸る嘉例川を污染した 場合, 上水道及び農業用水の利水や河川における内水面

図-1 地下水流向 
漁業に影響を及ぼすことから，污染地下水の拡散防止と 地下水浄化について, 次の修復目標を定めた.

(1) 不法投棄地からの污染拡散を防止すること

(2) 不法投棄地内の地下水污染の浄化（管理型処分場レベ ル）を図ること.

(3) 污染が拡散している隣接地の地下水污染の浄化（環境 基準レベル）を図ること.

なお，管理型処分場レベルとは，遮水壁により不法投 棄場所の地下水が周辺と隔離されることから, 遮水壁内 の地下水が管理型処分場の放流水レベル（環境基準の 10 倍值）まで浄化できれば，周辺に支障を生じる危機 的な状況ではなくなり，その後は処分場と同等程度の管 理で安全が確保されるという考え方で設定している.し たがって, 目標達成の評価は, 遮水壁内の平均的な地下 水の有害物質濃度が, すべての項目で環境基準の 10 倍 值以下となれば達成と判断することとした.

浄化対象とする有害物質は, 地下水中のジクロロメタ ン, 1,2-ジクロロエタン, トリクロロエチレン, テトラ クロロエチレン, ベンゼン，1,3-ジクロロプロペンの 6 物質とし，これら 6 物質を総 VOC と称することとする. なお，重金属は，地下水中に懸濁物質として存在し，不 法投棄場所の周辺地下水からは検出されなかったことか ら, 污染拡散リスクが高くないと考えられ, 浄化対象物 質とはしていない，また，参考として，有機污濁指標で ある BOD も調査した.

\section{(3) 修復期間}

浄化期間を 5 年間とし, 全体計画を表-2 のとおりと した.

遮水壁内の地下水の浄化は下式により算出し, 表-3
のとおり浄化の進行を予測した.

$$
\begin{aligned}
& C_{n}=\left((V-V t) \times C_{(r-1)}+V t \times C_{S}\right) / V \\
& C_{n}: \text { 浄化開始 } n \text { 日後の污染物質濃度 }(\mathrm{mg} / \mathrm{L}) \\
& C S: \text { 浸透水 }(\text { 処理水 }) \text { の污染物質濃度 }(\mathrm{mg} / \mathrm{L}) \\
& V: \text { 遮水壁内の地下水保有量 }\left(10,790 \mathrm{~m}^{3}\right) \\
& V t: \text { 処理水量 }\left(60 \mathrm{~m}^{3} / \text { 日 }\right)
\end{aligned}
$$

なお，CS は各物質の浄化の水質目標未満（目標值よ り $0.001 \mathrm{mg} / \mathrm{L}$ 低い值) の数值を与えた. また, 本研究で 提案する表-3 の総 VOC 濃度当量とは, 6 種の VOC の濃度

\begin{tabular}{|c|c|c|c|c|c|c|c|}
\hline \begin{tabular}{|ll} 
項目 & 年度 \\
\end{tabular} & 13 年度 & 14年度 & 15年度 & 16 年度 & 17 年度 & 18年度 & 19 年度 \\
\hline 対策工事 & & & & & & & \\
\hline 遮水壁の設置 & $\leftarrow$ & $\rightarrow$ & & & & & \\
\hline 水処理施設の設置 & & $\rightleftarrows$ & & & & & \\
\hline 揚水循環浄化 & & & $\leftarrow$ & & & & \\
\hline モニタリング & & & & & & & \\
\hline
\end{tabular}
をそれぞれの水質目標值（環境基準の 10 倍值）で除し， その総和を総 VOC 濃度当量と定義し, 進行管理指標とし

\begin{tabular}{|c|c|c|c|c|c|c|c|c|}
\hline 期間 & 浄化日数 & ジクロ如夘 & 1,2-ジク加多 & トリクロロエチレン & 神名吅エチレ & ベンゼ & 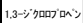 & 総VOC㯰度当量 \\
\hline 0年 & 0 & 20.000 & 5.000 & 0.400 & 0.300 & 0.700 & 0.020 & 237.3 \\
\hline 1 年 & 365 & 2.786 & & 12 & & 0.178 & 0.019 & 36.1 \\
\hline 2年 & 730 & & & 01 & 2 & 9 & 19 & 9.8 \\
\hline 3年 & 1095 & & & 299 & 9 & .100 & 0.019 & 6.4 \\
\hline & 1460 & & 0.040 & 0.299 & 099 & 0.099 & 0.019 & 6.0 \\
\hline 5年 & 1825 & 0.199 & 0.039 & 0.299 & 0.099 & 0.099 & 0.019 & 5.9 \\
\hline & & 0.2 & $\begin{array}{l}0.039 \\
0.04 \\
\end{array}$ & 0.3 & 0.1 & 0.1 & $\frac{0.02}{0.02}$ & $\langle 6$ \\
\hline
\end{tabular}
た（総VOC 濃度当量については後述する）。

表-2 環境修復計画

表-3 地下水の浄化計画

\section{(4) 主要設備}

\section{a）鉛直遮水壁}

表 -2 の全体計画に基づき, 污染地下水の拡散防止の

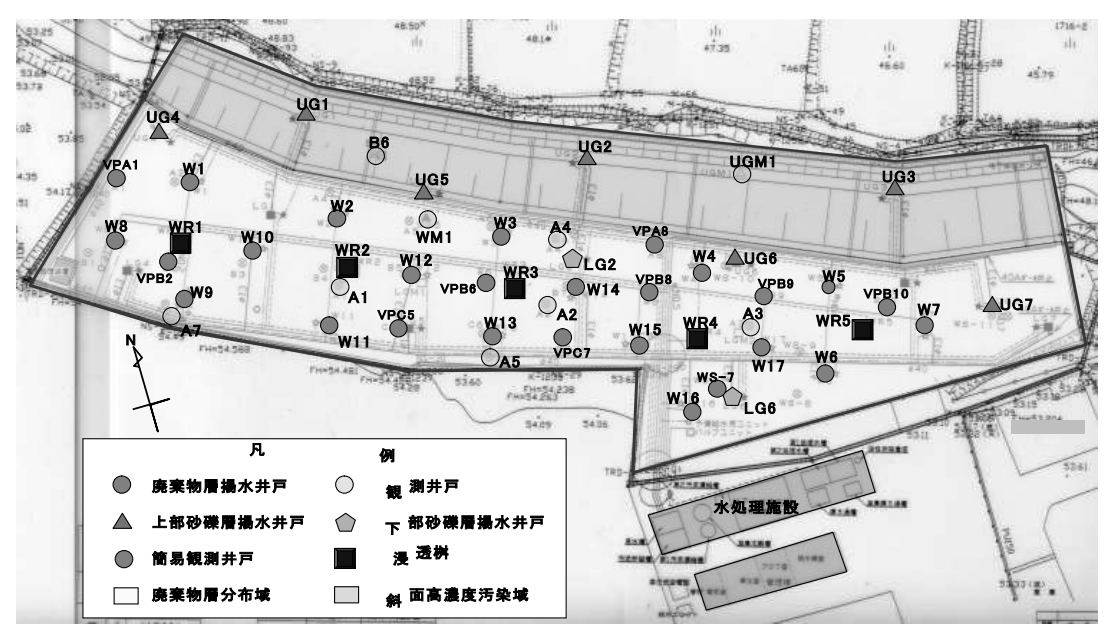

図-3 井戸配置 
ため, 当該場所 $2,906 \mathrm{~m}^{2}$ 之高濃度の污染地下水が拡散し た段丘地形の斜面部分 $907 \mathrm{~m}^{2}$ の計 $3,813 \mathrm{~m}^{2}$ に総延長 318 mのソイルセメント地中連続壁（芯材として $2.7 \mathrm{~mm}$ 特殊 軽量鋼矢板併用鉛直遮水壁）を設置した。遮水壁底部の 遮水地盤は, 標高約 $30 \mathrm{~m}$ （地表からの深度 $17 \sim 25.5$ m) の凝灰質シルト層であり，8 箇所の現場透水試験の 結果, 透水係数は $1.71 \times 10^{-6} \sim 1.45 \times 10^{-8} \mathrm{~cm} / \mathrm{s}$ の範囲で あり難透水性地盤と判断した。 なお，遮水壁根入れ部は, 凝灰質シルト層に $1.5 \mathrm{~m}$ 以上挿入するよう計画した.

\section{b) 水処理施設}

遮水壁内の污染地下水を浄化するために，水処理施設 として, 揚水設備, 浄化設備, 浸透設備を整備した.

揚水設備については，不法投棄場所の中央部で実施し た連続揚水試験の結果から平衡式による方法（Thiem の 方法） ${ }^{10)}$ により透水係数 $7.83 \times 10^{-3} \mathrm{~cm} / \mathrm{s}$ ，揚水井戸の影 響半径 $8 \mathrm{~m}$ と算定されたことから, 廃棄物層内の地下水 が揚水井戸の影響範囲となるよう均等に 17 本の揚水井 戸（W1〜W17）を配置した．さらに，污染が拡散してい る法面の污染地下水の浄化のため 7 本の揚水井戸 (UG1 〜UG7）を設置した（図-3）. 井戸は，共通の仕様で $\phi$ $114 \mathrm{~mm}$ のボーリング孔に塩ビ管(VP100)を挿入し, 対象 とする帯水層のオールストレーナー（ストレーナーの形 状 $\phi 15 \mathrm{~mm}$, 開口率 $10 \%$, 網 24 メッシュ $1 \mathrm{~mm}$ の 2 重巻 き）構造とした.

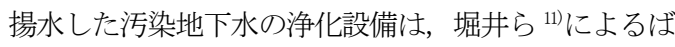
っ気一アルカリ凝集沈殿-生物処理-膜濾過-凝集沈殿-活 性炭吸着による処理工程とした. VOC に係る処理後の水 質は，環境基準の 10 倍值以下，また，BOD，COD，SS 除 去率は，それぞれ 90 \% , 90 \% ，99\%とした.

処理水は，5 箇所の浸透升（WR1〜WR5）から廃棄物層 一均等に注水した。

不法投㶳地内への雨水浸透防止対策として, 表層に $100 \mathrm{~mm}$ 厚のアスファルト遮水工を施工し, 法面部は 400

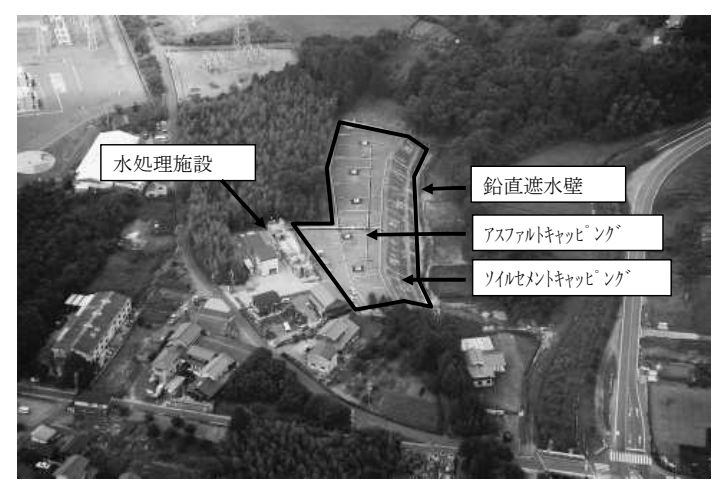

図-4 不法投棄場所全景 $\mathrm{mm}$ 厚のソイルセメント遮水工とした（図-4）。

\section{（5）地下水の調査地点及び評価方法}

地下水の浄化過程を評価するための水質検査は, 24 揚水井戸（W1〜W17 と UG1〜UG7） と補完的に設置した 17 観測井戸の計 41 地点で行った. さらに, 浄化促進対策 として追加設置した揚水井戸（NW1～NW4 と LNW1，LNW3, LNW4）においても，設置後に水質測定を実施し評価に加 えた. 各井戸における測定值は, 測定地点の垂直方向の 平均水質と考えた.

本研究の浄化対象地下水は, 複数の VOCで污染されて いることから, 式（2a）で定義した総 VOC 濃度当量を浄 化過程の進行管理指標とした. 総 VOC 濃度当量は, 6 種 の VOC の浄化目標值の超過倍率（当量）の和であること から, 6 種の VOC の污染の程度を統合的に評価でき, 複 数物質による污染はより高い值となり強調される特徵が ある.また, 各測定地点の総 VOC 濃度当量の等高線図 （コンター図）を作成することで, 污染残留箇所や追加 対策必要䇢所を特定しやすい利点がある. 浄化過程の評 価は，このコンター図を基に式(2b)により，遮水壁で囲 われた範囲の平面的な平均値, つまり加重平均等濃度当 量を算出し評価に用いた.

総 $V O C$ 濃度当量の加重平均值による目標達成の有無の 判定は, 6 以上の場合は目標未達成, 1 未満の場合は目 標達成と判断されるものの, 1 以上 6 未満の場合は当該 指標だけでは判定できず， 6 物質の個別評価により目標 達成の判定が必要である.

総 VOC 濃度当量 $=$ DCM/ $0.2+$ DCE $/ 0.04+$ TCE $/ 0.3$

$+\mathrm{PCE} / 0.1+\mathrm{DCP} / 0.02+\mathrm{BZN} / 0.1$ (2a)

DCM : ジ多哆濃度, DCE : 1,2-ジ吅工多濃度

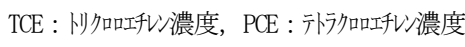

DCP : 1,3-ジ加プロペ濃度, BZN : ベ版濃度

加重平均値 $=\sum\left(\mathrm{C}_{\mathrm{n}} \cdot \mathrm{S}_{\mathrm{r}} / \mathrm{S}\right)$

$C_{\mathrm{n}}:$ 総 $V O C$ 濃度当量 (各物質濃度) $\mathrm{n}$

$\mathrm{S}_{\mathrm{n}}$ : 遮水壁内の総 VOC 濃度当量 (各物質濃度) $\mathrm{n}$ の面積

$\mathrm{S}$ : 遮水壁内面積 $\left(3,813 \quad \mathrm{~m}^{2}\right)$

浄化過程の評価は, 浄化段階として区分した初期対策, 第 1 浄化促進対策, 第 2 浄化促進対策の段階ごとに表-3 における当初計画の浄化予測等と必要に応じ比較して行 った. 


\section{4. 地下水浄化プロセスとその結果}

\section{（1）初期対策（2003.4～2005. 2)}

\section{a) 地下水の浄化経過}

2003 年 4 月から遮水壁内污染地下水の揚水を開始し た．揚水は，上部帯水層の廃棄物層に設置した W 井戸と 法面の UG 井戸の全てから概补均等に揚水を行った。揚 水した污染地下水は，水処理施設で処理し，全量を浸透 升に注水して循環浄化を行った。揚水開始初期から 2005 年 2 月（23 ケ月後）までの総 VOC 濃度当量及び月 間揚水量の推移を図-5に示寸。

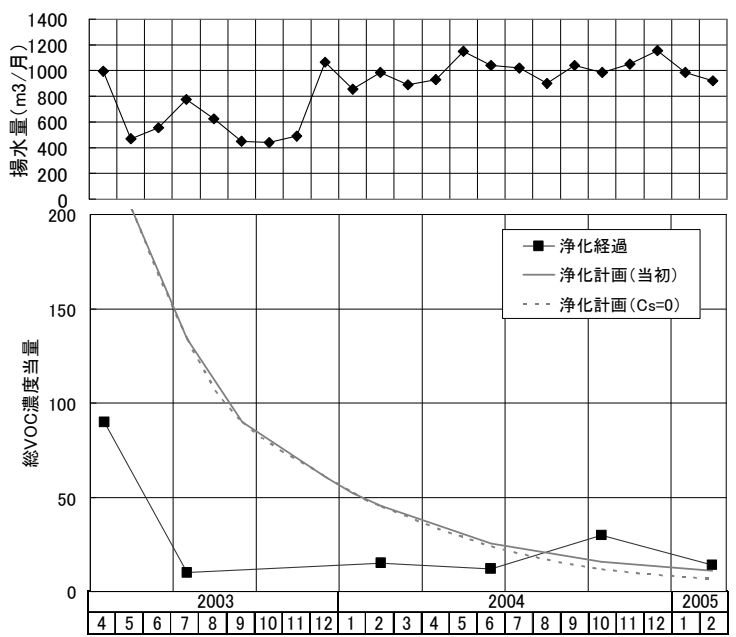

図-5 揚水量と総 VOC 濃度当量の推移

図-5 上段は揚水量の推移を示すが，揚水開始初期に は，地下水中の BOD が $2,900 \mathrm{mg} / \mathrm{L}$ と高濃度であり，生物 膜の形成による揚水井戸の閉塞や予測外の水の流入によ る遮水壁内地下水位の上昇，それに伴う法面からの地下 水の浸出のトラブル等が発生し, 2003 年 5 月から同年 11 月までの平均揚水量は, $544 \mathrm{~m}^{3} /$ 月であった. 揚水設 備の酸洗浄や揚水・注水量の一時的制限による運転管理 を行い，揚水開始から 9 ケ月後の 2003 年 12 月から概ね $1,000 \mathrm{~m}^{3} /$ 月の揚水が可能となった.

図-5 下段に処理水中の総 VOC 濃度当量の推移を示寸. 浄化過程が，当初計画どおりに進行しているかを評価 寸るため，図-5 に表-3 の浄化計画值もあわせて示した。 また，処理水中の VOC は，実測值において 6 物質の全て で定量下限値以下であったことから，式(1a)において， $C_{S}=0$ とし, この場合の浄化計画値も図 -5 に点線で示し た.

浄化開始 4 か月で総 VOC 濃度当量は 90 から 10 一低下 したが，その後，さらなる低下が認められなかったこと から，浄化促進を目的として，2004 年 11 月から不法投 棄場所の西側の污染残留箇所の $W 1, W 11, W 1,3$ 井戸の揚
水量を増加させる対策を講じた：それぞれの井戸の揚水 量をW1 が 5.8 倍，W11 が 1.8 倍，W1, 3 が 1.7 倍に増加さ せ，その結果，全体揚水量に占める割合が 3 井戸合計で $11 \%$ から $26 \%$ となった. しかし, 揚水量増加後の 2005 年 2 月においても著しい浄化促進効果は認められなかった。 初期対策における地下水浄化は，2003 年 4 月からの 初期の 4 か月で浄化計画を上回る急速な浄化が認められ たものの，その後は浄化の進展が認められず，2005 年 2 月では総 VOC 濃度当量は 14 であった.

\section{b) 課題之原因分析}

揚水循環浄化に伴う総 VOC 濃度当量のコンター図の推 移を図-6 に示寸。

図-6 から VOC の污染範囲は縮小し, 加重平均濃度当 量は，浄化開始 4 ケ月後に 90 から 10 一大幅な低下が認 められたが，その後の調査においては低下が認められず, 19 ヶ月後に 30 まで上昇した．その後，W1，W11，W1 の 3 つの污染残留井戸からの集中揚水により 23 ヶ月後は 14 となった．この経過の中で污染残留箇所は，浄化開始当 初から高濃度の污染地下水が存在していたことが判明し， 2005 年 2 月の総 VOC 濃度当量のコンター図において浄化 が滞っている箇所が，集中的な浄化対策が必要な箇所と して特定された。また，2004 年 10 月に総 VOC 濃度当量 が上昇したことは，廃棄物層からの新たな溶出により地 下水污染を生じている可能性があると推測された。

したがって，地下水の污染残留箇所は，廃棄物層の不 均一性から注水による浸透水の影響を受けにくい場所で あると考えられ，浄化を促進するためには，既設井戸か

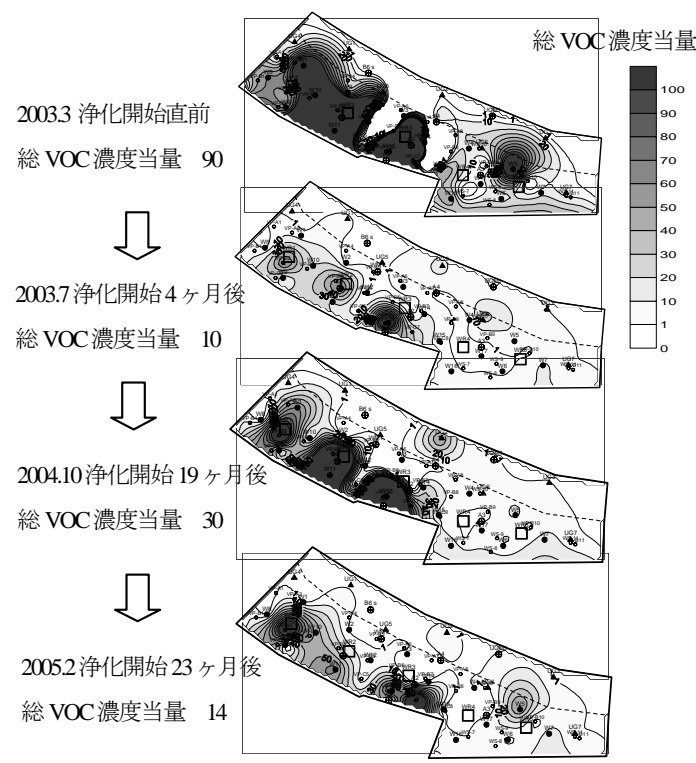

図-6 総 VOC 濃度当量の推移（2003.3～2005. 2) 
らの揚水量の増加だけでなく, 污染残留箇所一の井戸の 新設によるさらなる揚水により, 廃棄物に含まれる VOC の洗い流しを促進させる必要があることが示唆された.

（2）第 1 浄化促進対策 (2005.2 2007. 2)

\section{a) 揚水井戸の追加之効果}

初期対策における埩化過程の推移に基づく検証結果か ら, 図-6 の 2005 年 2 月のコンター図を基に, 污染地下 水が残留し，地下水の揚水による浄化促進をする必要が あると判断された 4 箇所に井戸の新設を計画し, 2006 年 2 月に井戸（NW1〜NW4）を設置した．図-7 の 2006 年 2 月の総 VOC 濃度当量のコンター図にその位置を示寸. 井 戸構造は，既存揚水井戸と同様である. 井戸設置後, 速 やかに浄化促進のために揚水を開始し，追加井戸及び既 設の污染残留箇所に設置した井戸から約 $800 \mathrm{~m}^{3}$ /月で集 中的な揚水を行った．なお，浄化完了井戸からの揚水は 停止した.

揚水井戸追加後の VOC 污染地下水の浄化の推移を図-7 に示す．追加井戸設置直後（追加井戸の揚水開始前）の 2006 年 2 月の総 VOC 濃度当量は 24 であり, 揚水循環開 始 3 个月後の 2003 年 7 月以降, 総 VOC 濃度当量の減少 はほとんぞ認められていなかったが，追加井戸を含めた 揚水浄化により，その 3 ヶ月後の 2006 年 5 月には 9.2, 12 ヶ月後の 2007 年 2 月には 5.1 まで浄化が進行した.

また， 2007 年 2 月の総 VOC 濃度当量コンター図では, 追加井戸 NW3 の周辺に污染の残存が確認できるが，高濃

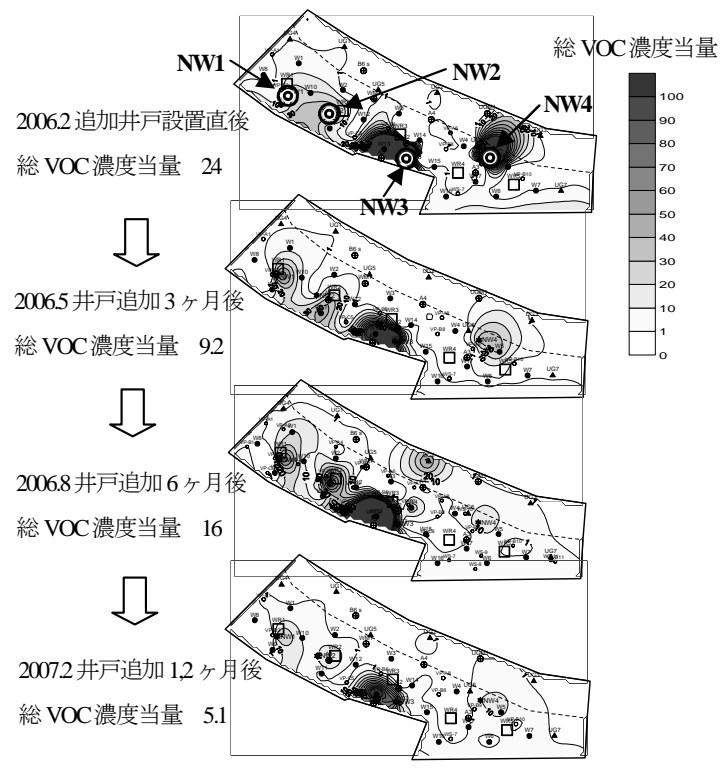

図-7 総 VOC 濃度当量の推移（2006. 2 2007. 2)
度污染の範囲は縮小している，その他の追加井戸設置箇 所は, 揚水循環浄化の効果により高濃度污染範囲は縮小 し，僅かに污染が確認される程度となった。

なお， 2003 年 7 月から 2004 年 10 月の浄化過程では総 VOC 濃度当量が上昇したことから, 廃棄物からの再溶出 等による影響を確認するため 試験的に 2006 年 6 月〜 2006 年 8 月の 3 ケ月間, 地下水の揚水循環を停止した. その結果， 3 ケ月の揚水停止で総 VOC 濃度当量は 9.2 か ら 16 に上昇した. しかし, その後の揚水循環浄化によ り, 再度総 VOC 濃度当量は低下したことから, 污染地下 水はすみやかに回収できていると判断された.

\section{b) 課題亡原因分析}

污染地下水の残留箇所に揚水井戸を追加することで高 濃度污染箇所の浄化が促進されたものの, 2007 年 2 月 の総 VOC 濃度当量のコンター図では，新設した NW3 付近 に高濃度の污染地下水の残留が確認された.

これまでの総 VOC 濃度当量の推移から見込まれる計画 期間終了時点（2008 年 3 月）の予測值を図-8 亿示す.

図-8 からこのまま揚水浄化を行った場合，計画期間 終了時点（2008.3.31）では, 総 VOC 濃度当量が 4.0 と見 込まれた. 総 VOC 濃度当量では, その值が 1 以上 6 未満 の場合は目標達成が判定できず 6 物質を個別に評価して 判定する指標である. したがって，個別物質において同 様の手法で推定したところ, ジクロロメタン, ベンゼン, 1,2-ジクロロエタンの 3 項目で目標期間内の浄化が困難 であることが判明した，それぞれの予測值は，ジクロロ メタン $0.51 \mathrm{mg} / 1$ （目標 $0.2 \mathrm{mg} / 1 ）$ ，ベンゼン $0.11 \mathrm{mg} / 1$

（目標 $0.1 \mathrm{mg} / 1 ） ， 1,2$-ジクロロエタン $0.07 \mathrm{mg} / 1$ （目標 $0.04 \mathrm{mg} / 1)$ であった. 当初計画における総 VOC 濃度当量 は表-3 より計画期間終了時点では 5.9 であり, 各物質 は目標を達成する計画であった。

以上より, 井戸追加による污染残留区域から集中的な 揚水を継続しても計画期間内に地下水浄化が完了しない ことが判明した。

揚水開始から 2007 年 2 月までの積算揚水量と污染残 留状況を図-9 に示寸. 図-9 では, 各揚水井戸の位置を



図-8 浄化進度と目標達成見込み 




総 VOC 濃度当量(2007.2)

図-9 積算揚水量と污染の程度

表-4 現場透水試験結果

\begin{tabular}{|c|c|c|c|c|c|}
\hline \multirow{2}{*}{ 調査地点 } & \multicolumn{3}{|c|}{ 調查深度 } & \multirow{2}{*}{\multicolumn{2}{|c|}{ 平均 }} \\
\hline & $\mathrm{GL}-4 \mathrm{~m}$ & $\mathrm{GL}-7 \mathrm{~m}$ & GL-9m & & \\
\hline NW1 & $1.48 \times 10^{-4}$ & $2.97 \times 10^{-5}$ & $1.52 \times 10^{-4}$ & $1.10 \times 10^{-4}$ & \\
\hline NW2 & $7.65 \times 10^{-5}$ & $3.56 \times 10^{-5}$ & - & $5.61 \times 10^{-5}$ & $1.79 \times 10^{-4}$ \\
\hline NW3 & $1.64 \times 10^{-4}$ & $4.10 \times 10^{-5}$ & \begin{tabular}{|l}
$3.17 \times 10^{-4}$ \\
\end{tabular} & $1.74 \times 10^{-4}$ & \\
\hline NW4 & $5.71 \times 10^{-4}$ & $2.41 \times 10^{-5}$ & $4.07 \times 10^{-4}$ & $3.34 \times 10^{-4}$ & \\
\hline
\end{tabular}

中心として，これまでの積算揚水量に比例した大きさの 円を描き，その円に 2007 年 2 月時点の総 VOC 濃度当量 に応じた着色をした，追加井戸に係る積算揚水量は，設 置から 1 年後までのデータ集計となっているため, NW2 を除き追加井戸の積算揚水量は少ない. これら揚水量の 少ない追加井戸（NW1，NW3，NW4）の周辺区域に設置し た既設井戸の積算揚水量もまた相対的に少ないといえる。 一方で NW2 は，揚水期間が短期であるにも関わらず，積 算揚水量が多く，浄化促進に高い効果があった.

井戸追加に併せて実施した現場透水試験の結果を表-4 に示す. 調查地点の全てで当初計画值 $7.83 \times 10^{-3} \mathrm{~cm} / \mathrm{s}$ より低い值であり，污染残留箇所は相対的に低透水性で あることが判明した。

なお，追加井戸のうち NW2 は他の追加井戸に比較して 揚水量が多いにも関わらず，表-4 では最も透水性が低 い結果となっている. 透水試験は, 調査深度における地 盤状態を表しており，不均質な廃棄物層では，廃棄物層 全体を代表するものにはならないと考えられるＮN2 の 地点は平均的には低透水性であるものの，特定の深度に 高い透水性を有する区域が存在すると考察される.

廃棄物層は，污染源が偏在しているだけなく，不法投 棄された廃棄物の種類や投棄方法（締め固めの程度）に もばらつきがあることから透水性も一定ではなく，その 結果，各井戸の揚水量にばらつきが生じ，浄化効果の違 いが発生したと考えられる. 特に，污染残留箇所は，集
中的な揚水によっても地下水の集水が十分でなかったと いえ，低透水性区域といえる.

こうしたことから，第 1 浄化促進対策での 4 箇所への 井戸追加は，浄化促進効果があったものの目標達成まで の見込みは得られず，その効果は限定的であり，併せて 3 か月の揚水循環净化の停止により 2006 年 8 月の総 VOC 濃度当量の上昇（図-7）したことから地下水の再污染も 明らかとなった。したがって，計画期間内に目標達成す るためには，廃棄物の洗い流しの促進も含めたさらなる 追加対策が必要であると判断された。

\section{(3) 第 2 浄化促進対策 (2007. 2 2008. 3)}

\section{a) 大口径揚水井戸の設置計画}

残留する污染地下水のさらなる浄化促進のための追加 対策は，既設の井戸構造では透水性の低い污染残留区域 からの集水が困難であり，廃棄物の洗い流し効果も期待 できないことから，集水能力が高く，かつ浄化困難な廃 棄物を部分的に除去できる大口径揚水井戸（LNW1，LNW3, LNW4）の設置とその井戸底からの水平ボーリングによる 集水が有効であると考えた．また，大口径井戸の設置に よりVOC を含む掘削廃棄物の処分及び周辺環境対策が必 要になるが，県内に処分施設が整備されたこと，局所的
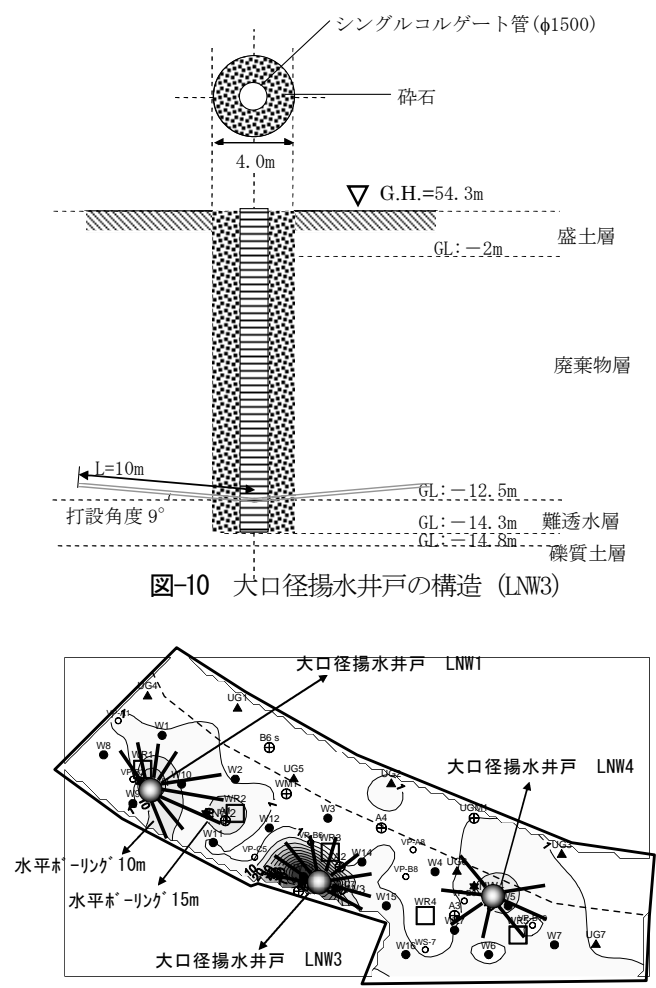

図-11 大口径井戸設置位置 
な掘削であり周辺環境対策が確実に実施できることから 污染残留箇所の廃棄物を現場外で処分する計画とした.

大口径揚水井戸は, 口径 $\phi 4,000 \mathrm{~mm} \times 3$ 井, 深度 $10 \sim$ $15 \mathrm{~m}$ (廃棄物層下端深度) , 水平ボーリング総延長 265 $\mathrm{m}(10 \mathrm{~m} /$ 本 $\times 22$ 本, $15 \mathrm{~m} /$ 本 $\times 3$ 本 $)$ として, 污染の残留 する 3 箇所に図-10 の井戸構造として設置した. 図-10 は, 大口径揚水井戸LNW3 の構造を示寸.

井戸径, 水平ボーリング長は, 廃萧物層内で安全に掘 削及び井戸底での水平ボーリングが施工でき，かつ，計 画期間内に除去すべき有害物質を含む污染地下水を集水 できる設計とし，また，その位置は，これまでの浄化の 推移を踏まえ 2007 年 2 月の総 VOC 濃度当量のコンター 図を基に図-11に示寸位置に計画した。

大口径揚水井戸は，ライナープレートによる深礎工法 で施工することから，設置工事前に遮水壁内の地下水を 低下させる必要があった. 2007 年 8 月，処理水を河川 放流寸ることに関し関係者の理解が得られたことから， 浸透升一の注水ではなく, 2007 年 9 月から工事の完了 まで全量を河川放流し, 遮水壁内の水位低下を図った. また，既設揚水井戸の孔口から硫化水素及びメタンが検 出されていたことから, 廃棄物層内での掘削作業にあた っては, 掘削坑内の空気置換の徹底と作業員の安全対策 （エアラインマスクや化学防護服等の装備），周辺環境 対策を図った。

計画では，2008 年 6 月〜9 月の工期を見込んだが，計 画，関係者の調整，施工等に時間を要し，大口径揚水井 戸の完成は 2009 年 2 月となった. 井戸設置後, 大口径 揚水井戸による揚水循環浄化を約 1 ケ月間実施した。 な
お, 井戸完成後, 水位回復のため遮水壁外地下水も注水 した.

\section{b)大口径揚水井戸による地下水浄化結果}

大口径井戸設置後の 2008 年 3 月, 計画期間終了時点 の総 VOC 濃度当量は, 図-12 に示寸とおり 1.1 となり, 高濃度污染箇所はほぼ消滅した。

浄化対象物質の各加重平均濃度は, 表-5 のとおり, すべての物質で目標值を達成した。

\section{5. 廃棄物及び地下水の評価 (1) 掘削廃棄物等調査結果}

大口径揚水井戸の設置時に掘削面を観察したところ, 宙水の存在が一部で確認されたものの, 鉄分の沈着等の 水みちの痕跡が確認できなかったほか, 掘削作業中は掘 削部分からの地下水の湧出がほとんど発生しなかった. 污染残留箇所の掘削廃棄物は, 全体的に黒色で自然含水 比 $21 \sim 54 \%$, 掘削体積及びその重量は, 3 箇所の合計で $425 \mathrm{~m}^{3}$ で 900t であったことから，その比重は 2.1 と算出 され, 密実に埋めたてられ低透水性であったと推定でき る.

また，掘削廃棄物の溶出試験を実施した，廃棄物の溶

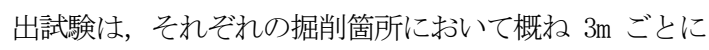
各掘削面から 3 検体を採取して溶出試験を実施し, 掘 削面の平均值を表-6 として取りまとめた.

表一 6 から，廃棄物層には埋立判定基準を超える污染 の残留が確認され, また, 污染の残留する深度は浅層と 深層で有意な差が認められなかった.

不法投棄場所の廃棄物に含まれるジクロロメタンの溶 出試験結果の経年変化を図-13 に示す．図-13 は, 1998



表-5 浄化結果

(単位 : mg/1)

\begin{tabular}{|c|c|c|c|c|c|}
\hline 項目 & 目標值 & $\begin{array}{c}\text { 浄化開始時 } \\
2003.3\end{array}$ & \begin{tabular}{|c} 
初期対策後 \\
2005.2
\end{tabular} & $\begin{array}{c}\text { 第1浄化促 } \\
\text { 進対策後 } \\
2007.2\end{array}$ & $\begin{array}{c}\text { 第2浄化促 } \\
\text { 進対策後 } \\
2008.3\end{array}$ \\
\hline ジクロロメタン & 0.2 & 11 & 1.6 & 0.42 & 0.13 \\
\hline 1,2-ジクロロエタン & 0.04 & 1.2 & 0.18 & 0.074 & 0.012 \\
\hline トリクロロエチレン & 0.3 & 0.25 & 0.020 & 0.01 & $<0.003$ \\
\hline テトラクロロエチレン & 0.1 & 0.29 & 0.018 & 0.011 & 0.002 \\
\hline 1, 3-ジクロロプロペン & 0.02 & 0.021 & 0.0016 & 0.0035 & $<0.0002$ \\
\hline ベンゼン & 0.1 & 0.39 & 0.19 & 0.16 & 0.062 \\
\hline
\end{tabular}

図-12 浄化結果（総 VOC 濃度当量）

表-6 掘削廃棄物溶出試験結果

\begin{tabular}{|c|c|c|c|c|c|c|c|c|c|c|c|c|c|}
\hline \multirow{2}{*}{ 項目 } & \multirow{2}{*}{ (単位) } & \multicolumn{3}{|c|}{ LNW1 } & \multicolumn{4}{|c|}{ LNW3 } & \multicolumn{4}{|c|}{ LNW4 } & \multirow{2}{*}{\begin{tabular}{|l} 
埋立判定潐 \\
作
\end{tabular}} \\
\hline & & GL-4. 0m & GL-6.5m & GL-8. 5m & GL-3. 5m & GL-6. 5m & GL-9. 5m & $\begin{array}{l}\mathrm{GL}- \\
12.5 \mathrm{~m}\end{array}$ & $\mathrm{GL}-3.5 \mathrm{~m}$ & GL-6.5m & GL-9. 5m & $\begin{array}{l}\mathrm{GL}- \\
11.0 \mathrm{~m}\end{array}$ & \\
\hline 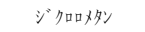 & $\mathrm{mg} / 1$ & 0.24 & 0.43 & 0.12 & 2.4 & 2.8 & 0.47 & 0.44 & 0.02 & 0.41 & 2.00 & 0.41 & 0.2 \\
\hline 1,2-ジクロ吅多 & $\mathrm{mg} / 1$ & 0.12 & 0.11 & 0.0004 & 1.3 & 1.3 & 0.0043 & 0.0035 & $<0.0004$ & 0.003 & 0.008 & $<0.0004$ & 0.04 \\
\hline 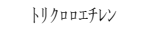 & $\mathrm{mg} / 1$ & 0.08 & 0.12 & 0.1 & 0.63 & 0.64 & 0.004 & 0.013 & 0.01 & 0.030 & 0.18 & 0.01 & 0.3 \\
\hline テトラクロ沃レ゙ & $\mathrm{mg} / 1$ & 0.17 & 0.39 & . & 1.4 & 0.90 & 0.019 & 0.009 & 0.11 & 0.14 & 0.20 & 0.06 & 0.1 \\
\hline 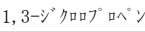 & $\mathrm{mg} / 1$ & $<0.0002$ & $<0.0002$ & $<0.0002$ & $<0.0002$ & $<0.0002$ & $<0.0002$ & $<0.0002$ & $<0.0002$ & $<0.0002$ & $<0.0002$ & $<0.0002$ & 0.02 \\
\hline ベンゼン & \begin{tabular}{|l|}
$\mathrm{mg} / 1$ \\
\end{tabular} & 0.077 & 0.056 & 0.021 & 0.51 & 0.61 & 0.031 & 0.074 & 0.014 & 0.075 & 0.11 & 0.012 & 0.1 \\
\hline
\end{tabular}


年から 2002 年の調査結果は任意の地点でのボーリング を実施した際に得られた検体を用い，また，2005 年及 び 2008 年は, 第 1 净化促進対策及び第 2 浄化促進対策 での污染残留箇所の掘削等で採取した検体を用いて溶出 試験を実施した結果を取り維めたものである．図中，各 年度の調查結果のばらつきを直線で範囲を示し，その平 均值を黒丸でプロットした.

調查年により検体数が異なるため，ばらつきに影響が あると思われるが，平均值に有意な減少は認められない， さらに, ジクロロメタン以外のトリクロロエチレン, テ トラクロロエチレン, ベンゼンでも同じ結果が得られた。 図-13 からは, 2005 年以降は污染残留箇所の結果である ことから，污染残留箇所では廃棄物の洗い流しの効果は ほとんど認められないと考えられる。

こうした污染残存箇所の VOC 残存状況，掘削面の観察 結果から, 污染残存箇所の廃棄物層は, 揚水循環浄化の 効果がほとんど認められない箇所となっていることが明 らかとなった。

また，污染残存䇢所に大口径揚水井戸設置後，僅かな 期間しか揚水していないにもかかわらず地下水浄化が促 進したことは、揚水循環浄化で浄化できない廃棄物が取 り除かれたことによる効果と考えられる.

大口径揚水井戸の掘削で除去した廃棄物量は，全体の 約 1.6\%（425/27,278）でしかなかったにもかかわ和ず, 地下水の浄化効果は非常に大きく, 原位置環境修復にお いても，短期間での地下水浄化を行う場合は，有効な工 法であるといえる.

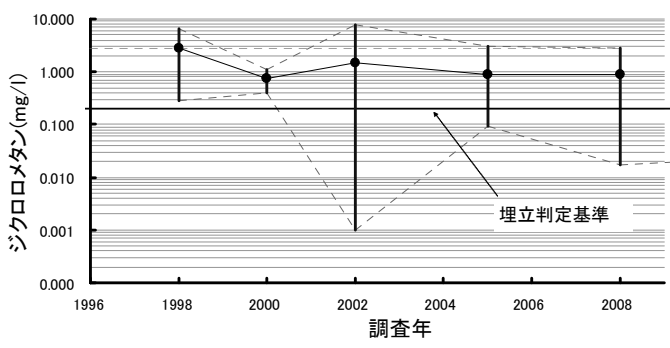

図-13 廃棄物溶出試験結果の経年変化

\section{（2）揚水量と地下水浄化}

地下水の 5 年間の総揚水量は, $39,335 \mathrm{~m}^{3}$ であり, 当初 計画揚水量 $109,500 \mathrm{~m}^{3}$ の約 $36 \%$ であったが，地下水浄化 は計画期間内に完了寸ることができた．揚水量が計画よ り少ないことは，井戸ごとに集水能力が異なり，集水能 力の高い井戸は浄化が初期に完了したことから揚水を停 止し，低透水性の污染残留箇所から揚水したことや再污 染の確認のための揚水停止が原因である. 一方で, 浄化 開始当初は揚水量が計画を大きく下回っているにも関わ
らず，浄化が急激に進行している，さらに，污染残留箇 所の廃棄物層の掘削調査の状況から, 廃棄物層内では地 下水が特定の流路に存在していたと考えられる状況であ ったことから, 不法投棄地内の地下水帯水量は, 有効間 隙率 0.2 として算出した当初推定值の $10,790 \mathrm{~m}^{3}$ を大幅 に下回っていた可能性がある. しかし, 遮水壁内の帯水 量の検証は，廃棄物層全体の状況をさらに詳細に把握す る必要があり, 今後の研究課題としたい.

\section{（3）地下水の再污染の可能性}

本研究により地下水の浄化は達成したものの, 污染残 留䇢所の掘削調查結果からは埋立判定基準を超過する有 害な廃棄物が確認できていることから，不法投棄された すべての廃棄物の有害性がなくなったとは考えられない，

目標達成後の 2008 年 4 月から揚水循環を停止し, 地 下水のモニタリングを行ったところ 2008 年 6 月の調査 結果は, 総 VOC 濃度当量が 0.92 であり, 地下水の再污 染は確認されていない，短期的な再污染は認められてい ないものの長期的には再污染のおそれが否定できないこ とから，今後もモニタリングを継続する必要がある。

\section{6. 結論}

廃棄物を残置したままの地下水浄化は，全量撤去が困 難な大規模な不法投充現場等においてで重要な技術であ るが，対策期間の長期化やそれに伴うコストの増嵩が課 題である. 本研究では, 三重県桑名市の不法投棄現場に おいて, 高濃度のVOC 污染地下水を揚水循環浄化工法に より，計画期間である 5 年間で管理型処分場の排水基準 レベル（地下水環境基準の 10 倍值）までの浄化を試み, 計画期間内の地下水浄化に必要な以下の評価手法やプロ セスを明らかにした。

(1) 廃棄物の不法投棄現場で, 初めて原位置環境修復技 術である揚水循環浄化工法を適用し，地下水浄化を 行った.

(2) 浄化対象とした 6 種の VOC を統合的に評価する総 $V O C$ 濃度当量と加重平均による指標を新たに提案し た.

(3) 総 VOC 濃度当量を用いてコンター図を作成すること で, 複数物質の污染であっても浄化効果を可視化し， 適宜追加的な対策を講じることで, 目標とした 5 年 間で地下水浄化を達成した.

(4) 污染残留区域の廃棄物層の透水性や廃葉物に残存寸 る有害物質量から污染が残留した機構を明らかにし た.

(5) 原位置環境修復においても污染残留区域の廃棄物を 
部分的に除去することで，短期間で地下水を浄化で きることを明らかにした。

最後に, 本研究では, 地下水浄化目標を達成したもの の, 污染残留箇所の掘削廃棄物に VOC が浄化されず残存 していたことが判明し，こうした未浄化の廃棄物が未だ 現地に存在する可能性は否定できない。しかし, 浄化困 難な廃棄物に含まれるVOC は, 逆に地下水中へも溶出し にくいとも考えられることから, 今後, 安全確保のため にモニタリングを行うなど適切な管理を継続して実施す ることとしている. さらに, 当該場所の維持管理期間は, 埋立物の性状から一般的な管理型処分場の廃止までの期 間より長期にわたることが予想されることから，管理期 間短縮に向け，VOC の物質収支の推計等のための調査を 実施するなどさらなる取り組みが必要になっていること から, 今後の研究課題としたい.

謝辞 : 本研究を行うにあたり, 水処理施設の維持管理, 管理記録の作成にご協力をいただいた種村榮一氏を始め とするクボタ環境サービス(株)及び(株)クボタの皆様, ならびに三重県廃棄物対策室の中村研二専門監, 沢西芳 円主査を始めとする皆様に, 謝意を表します.

\section{参考文献}

1)環境省報道発表資料: 産業廃裹物の不法投㶳の状況（平成 21 年度)について, 平成 22年 12 月 27 日.

2)環境省 HP : 産廃特措法に基づく特定支障除去等事業につい

$\tau$, http:/wwww.env.go.jp/recycleill_dum/tokuso.html

3)財団法人産業廃棄物処理事業振興財団: 不法投棄及び不適正 処理現場の対策と技術, pp.94-1,26,2010.

4) 古市徹, 谷川昇, 石井一英, 金相烈 : 廃衰物の不法投重対策 への総合的・体系的アプローチ, 廃衰物学会誌, Vol.18, No.2, pp.77-83, 2007.

5) 平田建正, 前川統一郎監修 : 土壤・地下水污染一原位置浄化 技術の開発と実用化, CMC 出版, 2004

6) 財団法人廃衰物研究財団: 廃書物の適正処理及びリサイクル に関寸る研究総合報告書, pp10-41,2000

7) 三重県 : 特定産業廃衰物に起因寸る支障の除去等に関する特 別措置法第 4条の規定に基づく実施計画, 2005

8)和田卓也, 井口昭則, 石井一英, 古市徹 : 高密度電気探查を 利用した廃裹物由来の土壌・地下水污染調查, 第 13 回廃衰物 学会研究発表会講演論文集, pp11,37-11,39, 2002.

9) Diane S Roote,P.G., In Situ Flushing, Technology Overview Report, Ground-Water Remediation Technologies Analysis Center, 1997.

10) 社団法人地盤工学会 : 地盤調查 基本と手引き, pp.165-172, 2005

11) 堀井安男, 寺尾康, 土本正明, 徳島幹治, 米津得雄一 : 原 位置フラッシング法による廃棄物不法投毒現場修復, 第 15 回廃衰物学会研究発表会講演論文集, pp1409-1411,2004.

(2011.8.8 受付)

\title{
ANALYSIS OF REMEDIATION PROCESS OF THE GROUDWATER COTAMINATION IN AN ILLEGAL DUMPING SITE
}

\author{
Norikazu NISHIDA， Toru FURUICHI， Kazuei ISHII
}

\begin{abstract}
Among on-site remediation technologies applied to illegal dumping sites, a technology to remedy contaminated groundwater without removal of the dumped waste is expected to provide a great opportunity to fulfill a societal need due to its economic advantage compared to removal of all waste. However heterogeneously-distributed waste makes the remedial process difficult. In this study, an in situ flushing technology was applied to an illegal dumping site in Kuwana city, Mie, in order to remedy groundwater contaminated with several volatile organic compounds (VOCs) within five years. The key to successfully achieve the target was to conduct a series of advanced remediation processes; introducing a new indicator by which multiple VOCs can be estimated integratelly, monitoring the progress of remediation with a contour map of VOC concentration as well as the weighted averages of the concentration derived from the indicator, pinpointing residual contaminants area, reexamining the plan, and taking additional steps that promote further remediation.
\end{abstract}

